\title{
A NEW ENGINEERING PROGRAM THAT INTRODUCES DESIGN WORKSHOP COURSES
}

\author{
Jean Brousseau, Université du Québec à Rimouski \\ Louis Cloutier, Université Laval \\ Bernard Larocque, Université du Québec à Rimouski \\ Jean-François Méthot, Université du Québec à Rimouski
}

\begin{abstract}
While the accreditation board clearly indicated which components that must be included in the engineering programs, we are free to arrange them so as to achieve our goals. It is the need for an engineering program oriented towards creativity, design ability and multidisciplinary approach, which led Université du Québec à Rimouski to include engineering workshops throughout the curriculum. The workshops use a problem based learning approach as distinct from the engineering science approach that has been the traditional norm. They allow the continual integration of knowledge and the development of designing skills. These workshops are arranged in a sequence, which assumes that design is a skill acquired with experience and based on a methodological process, tools and techniques. The paper describes the program's structure and the content of the design workshops. It gives examples of real problems solved by students. Finally, it presents and discusses the nature of the foreseen changes that will be brought to the program.
\end{abstract}

\section{Introduction}

Founded in 1969, the Université du Québec à Rimouski (UQAR), a constituent of the Université $d u$ Québec, has been offering an engineering degree program since September 1994. As a result of a vast consultation that included the business, industry, public and parapublic sectors, the program has been geared towards training versatile engineers capable of designing, implementing and analyzing elements and systems of the physical environment using a multidisciplinary approach, while considering ethical, social and economic factors. In the development of the program, the Université du Québec à Rimouski recognized that the practice of design is central to the education of the next generation of engineers. Engineering design is the process by wich raw scientific knowledge is encapsulated within useful products. The features and value of a product are largely determined by design.

When the program was established, significant reports concerning the future of engineering degree programs ${ }^{1-5}$ stated the importance of developing skills, which surpass the various topics touched upon in the curriculum. These studies insisted on the importance of a solid basic training in engineering science, additional training directed towards the professional practice, design 
engineering and systems integration, closer contact between the student and the business community, the ability to clearly communicate ideas, and to work efficiently in a team.

Over the past ten years, integrating design courses into engineering programs from the first to the last year of the curriculum has attracted much attention ${ }^{6-22}$. Although there were concerns that the technical knowledge of new students might be insufficient to undertake a course in design, experience now shows that these courses can be successfully integrated into engineering programs as early as the first year ${ }^{7-12}$.

Because design is a skill or behavior that is acquired with experience ${ }^{23}$ but also based on techniques and tools ${ }^{10}$, it is advisable to offer students the opportunity to gain various experiences throughout their education from courses in engineering science and also from project-oriented courses that specifically focus on design. This is why design must not be introduced only at the end of the program but rather throughout the full extent of the student's curriculum. UQAR's engineering program includes design workshops which aim to develop designing skills from the first to the last year of training. These workshops allow students to integrate knowledge and develop designing skills on a continuous basis while establishing contacts with companies. In the workshops, students initially acquire the tools and methodology required for the design of mechanical and electrical systems. They then work in a company, within the framework of the "On-site Training" workshop. Finally, under the supervision of departmental professors, students become initiated to the world of professional engineering and learn how to suggest real and innovative solutions to challenging design and R\&D problems submitted by companies. These design workshops are a distinctive feature of the new Electromechanical Systems Engineering program at the Université du Québec à Rimouski.

In this article, we describe the new program's structure and the integration of the design workshops within the student's curriculum. The teaching philosophy of the workshops is then presented and each workshop is described. We also present the steps involved in establishing the program according to the accreditation procedures and discuss the comments received from the Canadian Engineering Accreditation Board (CEAB). Thereafter, we discuss the difficulties encountered in offering the program. Finally, we review the future of our program and present the changes foreseen in the coming years.

\section{The program's structure}

The four-year program totals one hundred and twenty course credits. As shown in Figure 1, the program consists of five units: mathematics (13 credits), computer science (8 credits), engineering science (67 credits), complementary studies (15 credits), and design workshops (17 credits). The engineering science unit includes 57 mandatory and 10 elective credits. These courses cover the traditional disciplines of mechanics and electricity. Since the program offers the fundamentals of mechanical and electrical engineering, elective courses are limited to 10 credits. Thus, by a suitable choice of five optional courses of two credits, the student can specialize in one area or can reinforce the integration of the program's two disciplines. The elective courses are regrouped in three units: mechanics, computer aided manufacturing, and electrical engineering. 


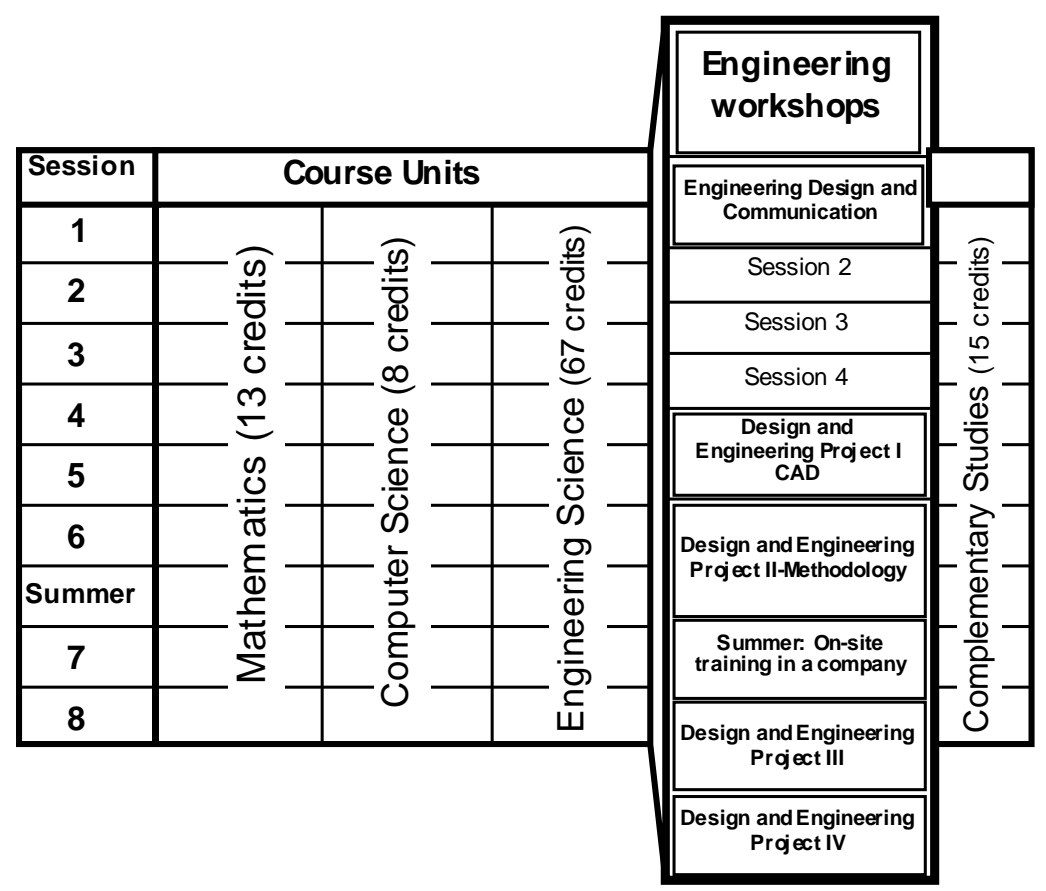

Figure 1: The program's structure

The design workshops, which are an important part of our program, begin with the "Engineering, Design, and Communication" workshop, followed by the project-oriented workshops "Design and Engineering Project I, II, III, and IV" and the "On-site Company Training".

Students have the opportunity of working in partnership with companies through internships and engineering projects. This paid training allows students to gain hands-on work experience in a company. The program offers two types of optional internships: short internships lasting 12 to 16 weeks or long internships lasting 28 to 32 weeks. The "Design and Engineering Project III and IV" workshops also offer a beneficial type of partnership with companies. Companies submit problems to the students who, by teamwork, must then find adequate solutions under the supervision of the engineering department's professors.

\section{Design workshops}

One can easily concede that engineering programs must train people who master the art of engineering and possess the scientific background to accomplish their tasks. However, it is important to stress the significance of design, manufacture, and production so that students learn to analyze and synthesize and develop a creative, inventive, and team spirit. Because, problem solving, designing, and technological innovation are daily tasks of the engineer, design practice must be an essential component of the curriculum.

While the accreditation criteria ${ }^{24}$ clearly indicate which components must be included in the teaching program, we are free to arrange them so as to achieve our goals more easily. It is the need for an engineering program oriented towards creativity and design ability ${ }^{6}$ which led UQAR to include design workshops throughout the curriculum, from the first to the last year. 


\section{The philosophy of the workshops}

In our program, design is seen as an essential element of the curriculum. The design workshops provide for a continuous integration of knowledge and designing skills. These workshops are arranged in a sequence which assumes that design is a skill acquired with experience and based on a methodological process, tools and techniques (see Figure 2). In the course of the first three workshops, students learn the methodology and the tools needed to design mechanical and electrical systems. Thereafter, students work in a company in the "On-site Company Training" workshop. This type of partnership teaches students about the intricate workings of the business community. Finally, students experience another form of partnership in the " Design and Engineering Project III and IV " workshops.

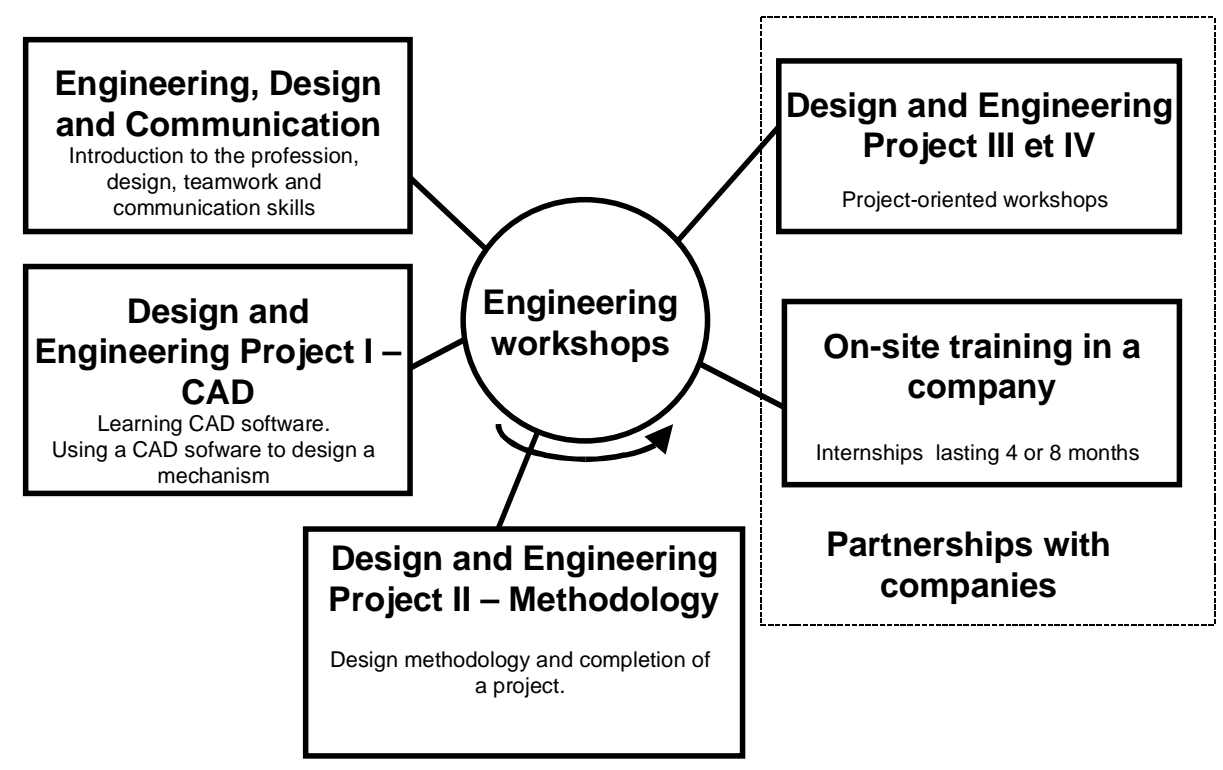

Figure 2: The philosophy of the design workshops

\section{The "Engineering, Design and Communication" course}

The "Engineering, Design and Communication" course is divided into three closely related sections. The engineering section examines the various sides of the profession: the fields of specialization, the duties and responsibilities of the engineer, and the role of the association of professional engineers. The second section reviews the methodology used to develop technical products based on Ulrich's ${ }^{25}$ procedure. Through teamwork and various projects, students must carry out the steps involved in developing a new product, from its conception to the manufacture of a prototype. The third section presents the fundamentals of interpersonal communication skills, efficient teamwork, technical writing and oral presentations. The six weekly hours are divided between lectures and work periods for team projects.

Essentially, students must carry out a short and long project, but they must complete several others projects for the course. These include making a simple object using a lathe and a milling machine as well as writing a text of 1500 words on the roles and responsibilities of the engineer. The short project is a designing competition between teams that takes place at the beginning of the year. The objective is to have students fully experience a design project while intuitively following the methodology used to develop a product. Technical concepts, related to the challenging problems, are discussed during project presentations and prototype testing. In the 
autumn 1997 session, we asked students to design and build a cardboard bridge measuring 0.5 meters in width and 1.5 meters in length between supporting props. Figure 3 shows the winning team's bridge.

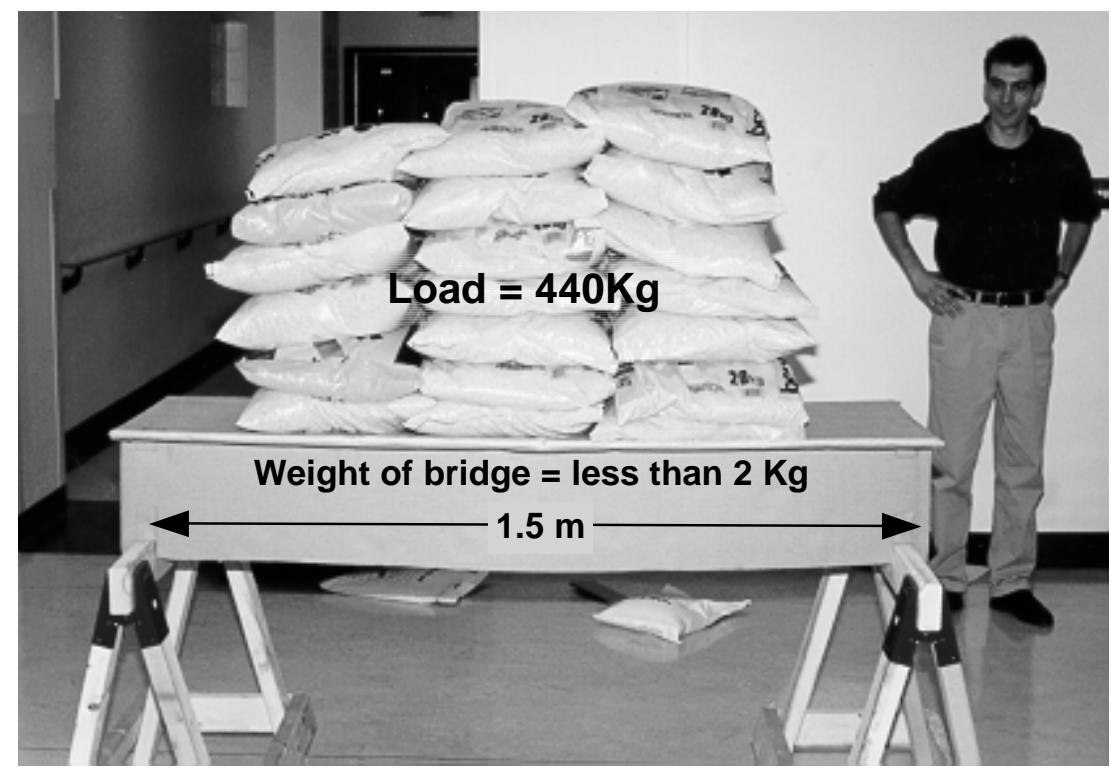

Figure 3: The winning team's bridge; short project.

The long project has a greater scope. Students devote approximately 12 weeks to the project, thus enabling them to go through all the steps involved in developing a product. The level of difficulty of the project takes into account that students are in their first engineering session. The evaluation of projects is based on progress reports, a final report, an oral presentation, the prototype and the project's logbook.

For the long project, the class is divided into teams using the Myers-Briggs Type Indicator $(\mathrm{MBTI})^{26-28}$. This indicator, based on Jung's theory, identifies 16 different psychological types. The MBTI model offers a way of integrating the positive differences resulting from the various ways with which individuals direct their attention, their modes of information seeking and decision-making, and also the lifestyles they adopt. Good teamwork calls for recognition and use of certain valuable differences between members of the team. Any team, therefore, should include a sufficient variety of types to perform effectively, and with satisfaction, the responsibilities of the team. However, cooperative between very opposite types can run into difficulties, because they so often disagree on what should be done, or how, or whether anything needs to be done at all. In this course, the MBTI model offers a way of introducing and discussing the fundamentals of working efficiently in a team.

In the 1996 and 1997 autumn sessions, we asked students to design a product for popularizing science for ASTER, a non-profit scientific interpretation center. Figure 4 shows a multiplexer and a toy windmill which can be used as an anemometer. The quality of the products they design shows clearly that the technical knowledge of new students is sufficient to undertake a course in design. There is no doubt, design courses can be successfully integrated into engineering programs as early as the first year. 

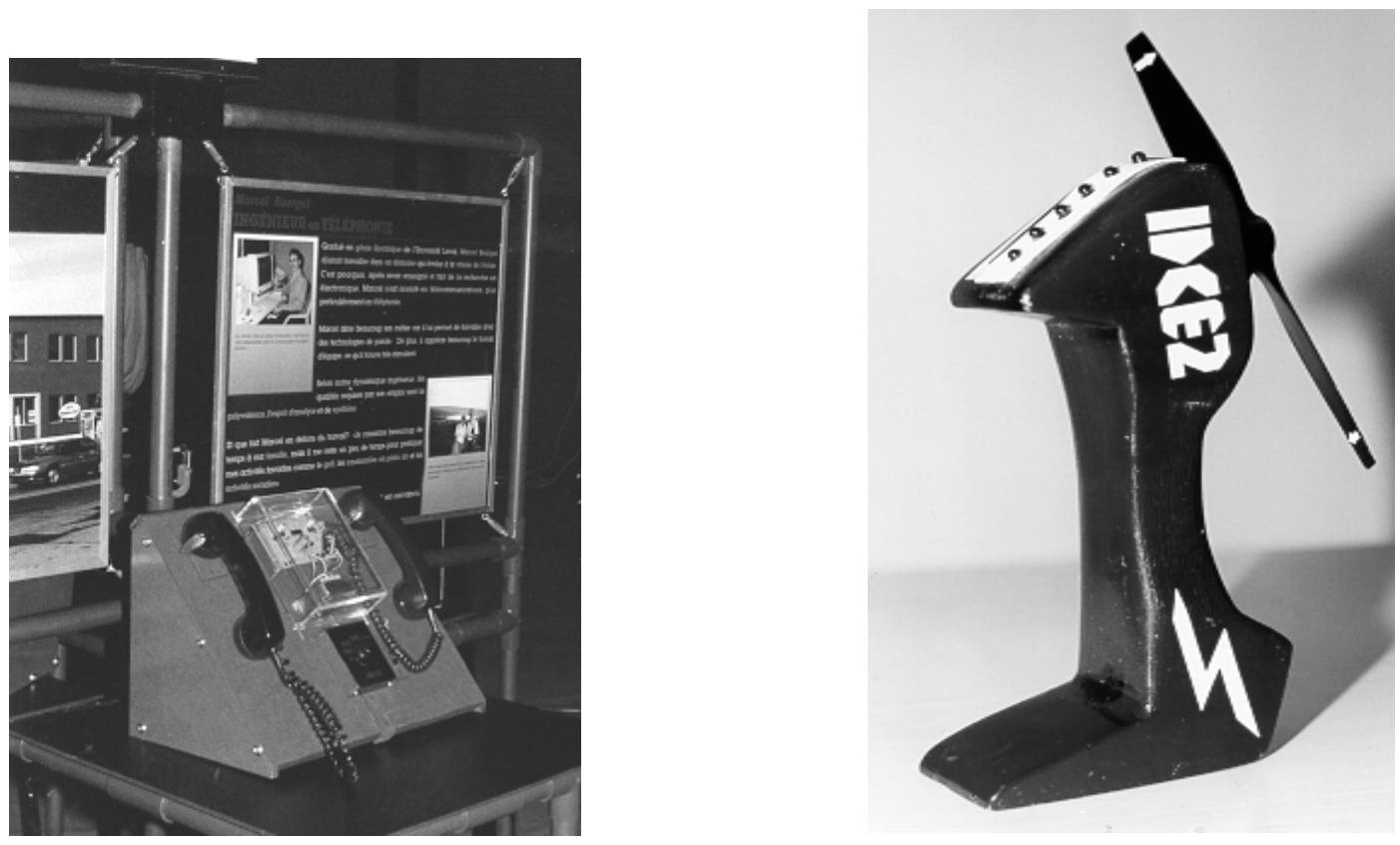

Figure 4 : Multiplexer and anemometer; long project.

\section{“Design and Engineering Project I - CAD” course}

The aim of this course is to give students the CAD tools needed for the design and dimensioning of mechanical systems. In the theoretical part of the course, the main topics studied are: geometrical modeling of curves, surfaces, and solids; basics of dimensional and geometrical tolerancing; standardized adjustments; and an introduction to finite element method in solid mechanics. In the practical part of the course, students learn to use CAD software. They also design a complete mechanism (solid models and drawings) for a term project.

\section{“Design and Engineering Project II, III, IV" course}

The objective of the "Design and Engineering Project II, III, IV" courses is to put into practice the methods of applied design to mechanical and electrical engineering projects. Real engineering problems of mechanical and/or electrical nature corresponding to the student's level of knowledge have to be solved. Projects are carried out in teams and are either submitted by an engineering professor, a company, an organization, or by the students themselves. The means of evaluation can vary according to the nature of the projects. The evaluation of students is based on two progress reports, a final report, drawings of the product, the prototype if necessary, an oral presentation, and a log book. Two professors, one in mechanical engineering and the other in electrical engineering, are in charge of the course. Professors and students work together as if they owned a company offering services in R\&D. Professors act as the managers of the R\&D. A management committee consisting of professors and a representative of each team is set up at each session. This committee meets on a regular basis and sees to the proper progression of the projects. 


\section{The "On-site Company Training" workshop}

The "On-site Company Training" workshop is an enriching form of partnership for both the students and the companies. These internships prepare students for the engineering profession by allowing them to gain practical hands-on job experience. They gain insight on how companies function and favor their integration to the labor force. Companies determine the content of the internship while keeping in mind the student's level of knowledge attained in the program. The tasks entrusted to students are related as closely as possible to those of an engineer. An engineer in the company must supervise the trainees.

\section{Partnerships with companies - a success}

Among the first 33 students that registered in the autumn 1994 program, 22 graduated in the spring of 1998 and 4 finished their program within the next year. This first group established contacts with 20 companies and organisms and participated in $\mathrm{R} \& \mathrm{D}$ projects that were supervised by professors from our department. All of the students participated in an internship and several of these resulted in projects that were used in the "Design and Engineering Project III and IV" workshops.

For example, a student did his internship and two "Design and Engineering Project III and IV" workshops with a professor from our department on a research project investigating the overheating of truck brakes. The student then decided to undertake graduate studies on the same subject. The space reserved for partnerships in our program makes it possible to establish interesting collaborations with companies. The following example is particularly convincing. A student was hired by a charcoal manufacturing company for his internship. In order to conform to environmental standards on atmospheric emissions, the company undertook in 1994, the installation of an incinerator allowing the smoke escaping from the furnaces to be burned safely (see Figure 5). After a one-year trial period, the system did not function adequately. During his internship, the student set up a pumping system for the pyroligneous condensates. The system proved to be effective for pumping very viscous tar. For the "Design and Engineering Project III" course, the student designed a device that, with a programmable controllers, made it possible to manage the air intake into the system. Finally, in his "Design and Engineering Project IV" course, he designed a pipe cleaning system for the supply pipe of the incinerator. At the end of his studies in engineering, the company offered him a job contract.

\section{From start-up to accreditation}

\section{The program's name and its orientation}

It is important to recall that UQAR had beforehand consulted not only companies in the field of engineering but also organisms such as the Canadian Council of Professional Engineers (CCPE) through numerous publications ${ }^{1-5}$. The multi-purpose character of engineering degree programs was absolutely impossible to ignore if one wanted to respect the recommendations put forth in these publications. UQAR wanted to ensure that all graduates obtain a solid basic training in mechanical and electrical engineering.

The name proposed for the program was Mechanical-Electrical Engineering. Not only does this engineering program distinguish UQAR from other Canadian engineering programs but produces particularly well trained young engineers who are able to face the requirements and challenges of 
a profession which is becoming more and more diversified and interdisciplinary. Without modifying the content nor the fundamental orientation of the program, the name was changed to Electromechanical Systems Engineering in June 98' since the Canadian Engineering Accreditation Board (CEAB) refused to register a program with a double name, wich could lead to a misintrepretation.

\section{Program accreditation}

An engineering program accredited by the (CEAB) allows its graduates to practice the profession and become members of the association of professional engineers. The accreditation process includes an in-depth visit by a visiting team and a thorough evaluation of the program ${ }^{24}$. The visiting team prepared a confidential report assessing the overall excellent quality of the new program and accredited it for a period of three years wich is the best result that a new program can obtain.

\section{The difficulties and the forseen changes}

\section{The difficulties}

Added to the difficulties encountered when establishing and starting any new engineering program were those associated with the distinctive characteristics of UQAR's engineering program. The integration of mechanical and electrical engineering requires the careful selection of activities providing sound training in both disciplines. This integration must avoid overlapping course material and be clearly defined in order to form a coherent unit rather than a regrouping of the two separate disciplines. This is why activities integrating both disciplines are favored to those of purely electrical or mechanical nature. Establishing design workshops brings forth a certain number of associated problems.

- Design workshops use teaching methods based on the supervision of students working in teams, which requires much time spent in class.

- The integration of knowledge from both disciplines occurs mainly during the design workshops. The choice of projects must be made according to this integration.

- Design workshops are based on projects. Thus, new projects must be found every trimester.

- Since projects are varied and always different, evaluating students in the workshops is difficult. This evaluation must take account the number of students in a team; the nature, complexity and scale of the project carried out; and the degree of completion of the project. Moreover, certain projects continue from one session to another.

- The multidisciplinary character of the projects and their scope often requires the consultation of external resource persons to help with certain design challenges that touch on complementary subjects.

\section{Foreseen changes}

After having offered the program for five years, it is worth identifying the nature of the foreseen changes. These aim to refine the program and to better achieve the goals of engineering degree programs, which include versatility, technical design, system engineering and integration of the complementary aspects of the formation.

- We plan to combine a few required courses and make compulsory certain elective courses in order to offer an even more extended and balanced basic training in the fields of mechanical and electrical engineering. 
- We wish to increase the number of design workshops in order to favor the integration of knowledge and to develop designing skills. We will replace the "Design and Engineering Project II - Methodology" course by the two following courses: "Mechanical Design" and "Electrical Design". Thus, all students will necessarily have to carry out a project in mechanics and electricity.

- We believe that all elective courses should be worth three credits in order to offer specialized optional activities making it possible to reach a higher level of training.

\section{Conclusions}

The design process is critical to the economic well being of any developed country. In the past, design is not an area wich attracted particualr attention in society at large, nor does it receive the attention or status it needed within University based Engineering Programs.

The Electromechanical Systems Engineering program offered by the Université du Québec à Rimouski offers an education centered on systems design which integrates the fields of electrical and mechanical engineering. The design workshops allow the continual integration of knowledge and to develop designing skills. These workshops are arranged in a sequence which assumes that design is a skill acquired with experience and based on a methodological process, tools and techniques. In the workshops, students initially acquire the tools and methodology required for the design of mechanical and electrical systems. They then work in a company, within the framework of the "On-site Training in a Company" workshop. Finally, they experience another form of partnership in the "Design and Engineering Project III and IV" workshops. Under the supervision of departmental professors, students learn how to suggest real and innovative solutions to challenging design and $\mathrm{R} \& \mathrm{D}$ problems submitted by companies.

The accreditation process has made it possible to confirm the choices that the university has made in developing its engineering program geared towards training versatile engineers capable of designing, implementing and analyzing electromachanical systems. Only the name of the program caused a real problem for accreditation since the Canadian Engineering Accreditation Board (CEAB) refuses to register programs with a double name in order to avoid any confusion. This is why the name of our program was changed from Mechanical-Electrical Engineering to Electromechanical Systems Engineering.

Following these first four years, it is possible to identify the nature of the changes to be brought to the program. We believe that it would be possible to increase the number of design workshops and to offer an even more extended and balanced basic training in mechanical and electrical engineering.

\section{Acknowledgments}

We wish to thank all the people who contributed in establishing the program. We also wish to thank the Quebec and Canadian governments who supported the program's implementation. 


\section{Bibliography}

1. Massachusetts Institute of Technology Commission, "Made in America : Regaining the Productive Edge", 1989, MIT Press.

2. Conseil Canadien des ingénieurs / Comité national des doyens en génie et en sciences appliquées, "L'avenir de la formation des ingénieurs au Canada", Octobre 1992

3. Académie canadienne du génie, "La formation des ingénieurs dans les université canadiennes", Septembre 1993

4. Ordre des Ingénieurs du Québec, "Mémoire au conseil des université sur l'étude sectorielle en génie”, Octobre 1992, OIQ

5. Ordre des ingénieurs du Québec, "Rapport du la formation des ingénieurs Québecois", Novembre 1996, OIQ

6. Cloutier, Louis, "Formation en génie : une place pour des ateliers d'ingénierie, de la première à la dernière année du programme", Congrès canadien de l'éducation en ingénierie, Queen's University, Kingston, Ontario, 16 au 18 juin 1996

7. Ambrose Susan A., et Amoon Cristina H., "Systematic Design of a First-Year Mechanical Engineering Course at Carnegie Mellon University", Journal of Engineering Education, April 1997.

8. Wilczynski V. et Douglas S.M., "Integrating Design Across the Engineering Curriculum : A Report From the Trenches, Journal of Engineering Education, July 1995

9. Bordogna Joseph, Fromm Eli et Ernst, Edward W., "Engineering Education : Innovation Through Integration", Journal of Engineering Education, January 1993.

10. Dally J.W., Zhang G.M., "A Freshman Engineering Design Course”, Journal of Engineering Education, April 1993.

11. Dym Clive L., "Teaching Design to Freshmen : Style and Content", Journal of Engineering Education, October 1994.

12. Richards Larry G., Carlson-Skalak Susan, "Faculty Reactions to Teaching Engineering Design to First Year Students", Journal of Engineering Education, July 1994.

13. Peterson, C.R., Why Integrate Design, ASEE Prism, May, 1993, pp. 26-29

14. Evans, D.L., McNeil B.W., Beakley, G.C., "Design in Egineering Education : Past Views of Future Directions", Engineering Education, July/August 1990.

15. Young, Jack H., Lasher, William C., "Designing Design into an Undergraduate Engineering Program", 1992 ASEE Annual Conference Proceedings.

16. Bordogna Joseph, "Entering the '90s : A National Vision for Engineering Education", Engineering Education, November 1989.

17. Monteith L.K., "Engineering Education - A century of Opportunity", Journal of Education, January 1994.

18. Moriarty Gene, "Engineering Design : Content and Context", Journal of Engineering Education, April 1994.

19. Starkey John M., Ramadhyani S., Bernhard, Robert J., "An Introduction to Mechanical Engineering Design for Sophomores at Perdue University", Journal of Engineering Education, October 1994.

20. West Harry, "A Criticism of an Undergraduate Design Curriculum", DE-Vol.31, Design Theory and Methodology, ASME 1991.

21. Dutson Alan J., Todd Robert H., Magleby Spencer P., Sorensen Carl S., "A Review of Litterature on Teaching Engineering Design Throught Project-Oriented Capstone Courses" Journal of Engineering Education, January 1997.

22. ASME, "Innovations in Engineering Design Education - Ressource Guide", American Society of Mechanical Engineers, N.Y. 1993.

23. Koen, Billy V., "Toward a Strategy for Teaching Engineering Design", Journal of Engineering Education, July 1994.

24. Canadian Council of Professionnal Engineers - Canadian Engineering Accreditation Board, "Accreditation Criteria and Procedures" 1998

25. Ulrich, K.T., et Eppinger, S.D., "Product Design and Development", McGraw-Hill, 1995

26. McCaulley Mary H., "The MBTI and Individual Pathways in Engineering Design”, Engineering Education, July 1990.

27. Briggs Myers Isabel, Myers Peter B., "Gifts Differing - Understanding Personality Type", CPP Books, Palo Alto, California, 1993.

28. Briggs Myers Isabel, “Type and Teamwork”, CAPT Publication, 1979. 


\section{Biographical Information}

\section{JEAN BROUSSEAU}

Jean Brousseau is a professor of Electromechanical Systems Engineering at Quebec University at Rimouski. He teaches Design, Computer Aided Design, Machine Elements and FEM. Dr. Brousseau received a Ph.D in Mechanical Engineering from Laval University in 1994. . He is a registred Professionnal Mechanical Engineer in Quebec Province and he conducts research activities mainly in topics related to machine design and finite element methot.

\section{LOUIS CLOUTIER}

Louis Cloutier is a professor of Mechanical Engineering at Laval University. He is a registred Professionnal Mechanical Engineer in Quebec Province and is actively involved in joint research with industry. Dr. Cloutier received a Ph.D. in Mechanical Engineering from Laval University in 1966.

\section{BERNARD LAROCQUE}

Bernard Larocque is a professor of Electromechanical Systems Engineering and the Engineering program director at Quebec University at Rimouski. He teaches Statics and Dynamics. He received a B.Sc. in Physics, a M.Sc. in Physics, and B.Sc.A. in Electrical Engineering from Laval University.

\section{JEAN-FRANÇOIS METHOT}

Jean-François Méthot is a professor of Electromechanical Systems Engineering at Quebec University at Rimouski. He teaches Design, Electronic and Computer Architecture. Dr. Methot received a Ph.D in Electrical Engineering from Laval University in 1995. . He is a registred Professionnal Mechanical Engineer in Quebec Province and he conducts research activities mainly in topics related to computer vision. 